\title{
Sero-prevalence of unvaccinated adolescent girls susceptible to rubella virus infection seen in a tertiary care hospital of Patna, Bihar, India
}

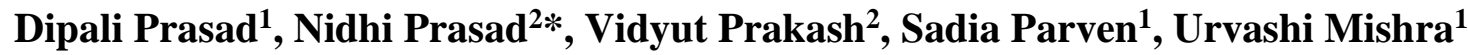

\begin{abstract}
${ }^{1}$ Department of Obstetrics and Gynecology, IGIMS, Patna, Bihar, India
${ }^{2}$ Department of Virology, IGIMS, Patna, Bihar, India
\end{abstract}

Received: 17 February 2020

Revised: 19 March 2020

Accepted: 27 March 2020

\author{
*Correspondence: \\ Dr. Nidhi Prasad, \\ E-mail: prasadnidhi72@gmail.com
}

Copyright: ( $)$ the author(s), publisher and licensee Medip Academy. This is an open-access article distributed under the terms of the Creative Commons Attribution Non-Commercial License, which permits unrestricted non-commercial use, distribution, and reproduction in any medium, provided the original work is properly cited.

\begin{abstract}
Background: Rubella infection occurring during early pregnancy results in congenital rubella syndrome (CRS). WHO estimates that worldwide more than 100,000 children are born with CRS each year and most of them are in the developing countries. For assessing population immunity against rubella, sero-surveys are generally recommended among adolescent girls and reproductive age female. In India, sero-surveys conducted by different authors have indicated that about $10-30 \%$ of adolescent females are susceptible to rubella infection. Adolescent girls are selected because they are at a critical stage of child bearing age and their immunity against Rubella infection is the particular area of interest. objective of this study was to estimate the sero-prevalence of unvaccinated adolescent girls susceptible to Rubella virus infection attending a tertiary care hospital of Patna and then accordingly counsel for vaccination.

Methods: A total 150 adolescent girls in the age group of 10-19 years who had not received MMR vaccine were included in the study. Serum IgG antibody titer for rubella was estimated by the ELISA method.

Results: A total $65.33 \%$ of the adolescent girls were found to be rubella seropositive and (34.67\%) were seronegative. The urban adolescent girls had a higher seropositivity of $85.2 \%$ as compared to rural adolescent girls.

Conclusions: The study indicates that a substantial number of adolescents $(34.67 \%)$ are seronegative and hence susceptible to rubella infection.
\end{abstract}

Keywords: Adolescent girls, Congenital rubella syndrome, Rubella susceptible, Seroprevalence, Vaccination

\section{INTRODUCTION}

Rubella infection occurs worldwide. Almost 50 to $65 \%$ of the infections is asymptomatic. Rubella infection occurring during pregnancy results in abortion, stillbirth and complications in the new born called congenital rubella syndrome (CRS). The risk of severe fetal anomalies is highest when rubella infection is acquired during the first 16 weeks of pregnancy. ${ }^{1}$

Congenital rubella syndrome is characterized by microcephaly, cataract, pigmented retinopathy, microphthalmia, sensorineural deafness, cardiac anomalies predominantly patent ductus arteriosus and pulmonary artery stenosis, intellectual disability, low birthweight, thrombocytopenic purpura, jaundice and hepatosplenomegaly. ${ }^{2}$ The United States documented the elimination of endemic rubella and CRS in 2004 and this was sustained through $2011 .{ }^{3}$ However, rubella continues to be endemic in many parts of the world.

WHO estimates that worldwide more than 100,000 children are born with CRS each year and most of them are in the developing countries. Sero surveys conducted in different parts of India have found that 5 to $67 \%$ of women are susceptible to Rubella infection. ${ }^{4}$ 
With the goal of preventing congenital rubella syndrome that results in devastating health burden, Indian academy of paediatrics has also recommended 2 doses of MMR for children. ${ }^{5}$ Indian academy of paediatrics revised schedule 2016-17 (IAP) for routine vaccination administer 1st dose of MMR at age 9-month through12-month, $2^{\text {nd }}$ dose15 months through 18 months and $3^{\text {rd }}$ dose 4-year through 6year.

In 2012 the Measles Initiative, now known as the Measles and Rubella Initiative launched a new Global Measles and Rubella strategic plan for the period 2012-2020. The plan includes goals to achieve measles and rubella elimination in at least 5 WHO regions by the end of 2020 . India has a huge birth cohort of 27 million. CRS is a preventable cause of mental retardation, childhood blindness and deafness, which has life-long special health and social needs.

The endemicity of rubella has been well established in India. But official data regarding the prevalence of acquired and congenital rubella infection is not available as rubella infection is not a notifiable disease. Since CRS and other complications can be prevented by vaccination of non- immune female, it is necessary to determine the susceptibility of adolescent and adult non-pregnant females to rubella virus infection.

Rubella containing vaccine is not routinely administered to adolescent children as catch up vaccine in the government healthcare policy. This study will have conducted to estimate the seroprevalence of rubella among unvaccinated adolescent girls. This provides an estimate of the epidemiologic burden of Rubella in the community. Adolescent girls will be selected because they are at a critical stage of child bearing age and their immunity should be a particular area of interest. The future looks towards eliminating rubella and congenital rubella syndrome due to the devastating complications.

Keeping these things in mind we decided to do a seroprevalence study on adolescent girls by serological test (blood) to determine the rubella virus immune status and also identify non-immune women susceptible to rubella infection, so that we can counsel them to get vaccinated to reduce the incidence of CRS and other complications. This study was done before the start of national campaign of administered the MR vaccine for school children between 9-month to 15-year of age.

The aim of this study is to determine the seroprevalence of adolescent girls susceptible to primary rubella virus infection and then accordingly counsel for vaccination coming to obstetrics and gynecology department of IGIMS, Patna, Bihar, India.

\section{METHODS}

This cross-section seroprevalence study of one year were done on all apparently healthy, adolescent girls coming to gynecology and obstetrics department in collaboration with virology department of IGIMS, Patna. Study was done on 150 girls between age group 10 to 19 years of unvaccinated adolescent girl. In order to determine the rubella serology, $2 \mathrm{ml}$ venous blood sample was be collected, serum was separated and serum IgG level was measured by qualitative ELISA method using Cal biotech kit following the manufacturer's instructions. Presence of Rubella IgG antibody in adolescent age group implied immunity and absence of Rubella IgG antibody implied susceptibility of such cases to rubella infection. Chi square test applied to find out significant difference.

\section{Inclusion criteria}

- All apparently healthy, adolescent girls coming to obstetrics and gynecology department of IGIMS who were non vaccinated or not aware of the vaccination status.

\section{Exclusion criteria}

- Females not in adolescent age group

- Females with signs and symptoms suggestive of any recent upper respiratory tract infection

- All rubella/MMR vaccinated females in adolescent age group.

\section{RESULTS}

In this study a total of 150 adolescent girl's age 10-19 (mean age - 15 years) years were enrolled. Ninety-eight $(65.33 \%)$ of adolescent girls were seropositive and fiftytwo $(35 \%)$ of adolescent girls were seronegative and hence susceptible for rubella infection (Figure 1).

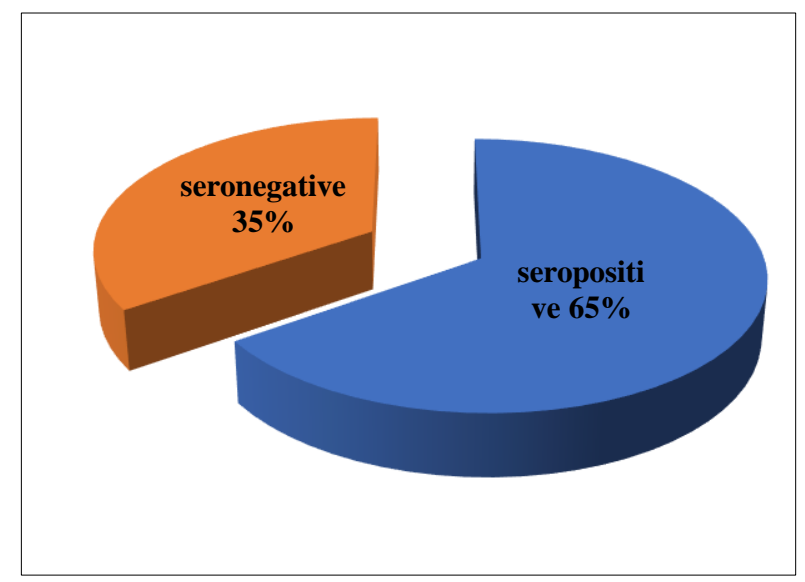

Figure 1: Percentage of seropositive and seronegative adolescent girls to rubella IgG.

This study revealed the prevalence of seropositivity to be $4.08 \%, 23.47 \%$ and $72.45 \%$ among $10-13$ years, $14-16$ years and 17-19 years respectively (Table 1).

According to modified Kuppswami scale for socioeconomic status (SES), $2.66 \%$ of adolescent girls 
belong to SES I, $9.3 \%$ to SES II $64.6 \%$ to SES III, $16 \%$ to SES IV and $7.3 \%$ of adolescent girls were in SES V (Table 2).

Table 1: Age wise distribution of seropositive and seronegative cases of rubella IgG.

\begin{tabular}{|lll|l|}
\hline Age & $\begin{array}{l}\text { No. of } \\
\text { patient }\end{array}$ & Seropositive & Seronegative \\
\hline 10-13 years & 6 & $4(4.08 \%)$ & $2(3.84 \%)$ \\
\hline 14-16 years & 32 & $23(23.47 \%)$ & $9(17.30 \%)$ \\
\hline 17-19 years & 112 & $71(72.45 \%)$ & $41(8.84 \%)$ \\
\hline Total years & 150 & $98(65.33 \%)$ & $52(34.66 \%)$ \\
\hline
\end{tabular}

Table 2: Socioeconomic status of adolescent girls participated in study (as per modified Kuppswami scale).

\begin{tabular}{|ll|}
\hline Socioeconomic status \\
\hline I & $4(2.66 \%)$ \\
\hline II & $14(9.3 \%)$ \\
\hline III & $97(64.6 \%)$ \\
\hline IV & $24(16 \%)$ \\
\hline V & $11(7.3 \%)$ \\
\hline Total & $150(100 \%)$ \\
\hline
\end{tabular}

Table 3: Number and percentage of seropositive and seronegative participants according to state of living.

\begin{tabular}{|llll|}
\hline $\begin{array}{l}\text { State of } \\
\text { living }\end{array}$ & $\begin{array}{l}\text { Total no. of } \\
\text { participants }\end{array}$ & $\begin{array}{l}\text { No. of } \\
\text { Seropositive }\end{array}$ & $\begin{array}{l}\text { No. of } \\
\text { Seronegative }\end{array}$ \\
\hline Urban & $131(87 \%)$ & $86(65.64 \%)$ & $45(34.36 \%)$ \\
\hline Rural & $19(13 \%)$ & $12(63.15 \%)$ & $07(36.85 \%)$ \\
\hline
\end{tabular}

In this study we found that seropositivity was nearly same among Urban (65.64\%) and Rural (63.15\%) participants. Although number of rural participants (13\%) was less than urban (87\%) participant (Table 3).

\section{DISCUSSION}

Although rubella infection is a mild, exanthemata's, febrile illness in childhood and adults but it can be a potentially threating event for the developing fetus in utero as it put it at risk of developing intrauterine death, premature birth or congenital rubella syndrome (CRS). Rubella is an infection that can be screened in females by performing serological tests. The future looks towards eliminating rubella and congenital rubella syndrome due to the devastating complications. Goals to eliminate rubella and CRS have been established in the WHO Region of the Americas (by 2010) and the WHO European Region (by 2015); furthermore, the WHO Western Pacific Region has established targets for accelerated rubella control and CRS prevention by 2015 . $^{6}$ More than $90 \%$ of the countries in North America and in the European region have included rubella in routine immunization. In India also there must be widespread introduction of currently available rubella vaccines to prevent congenital Rubella Syndrome.

In this study, $(34.67 \%)$ of adolescent girls were seronegative indicating their susceptibility to acquire rubella infection. Study from Chennai by Ramya $\mathrm{R}$ et al showed that $(21.3 \%)$ of the adolescent girls were sero- negative. ${ }^{7}$ Another study from Tamil Nadu done in 2004 showed that $(13.5 \%)$ of the adolescent girls were sero -negative. ${ }^{8}$

In this study, sero-positivity was higher in urban population as compared to rural. This finding is in concurrence with a study from Maharashtra by Sharma HJ et al. ${ }^{9}$ Most of the western world has eliminated congenital rubella syndrome since 2004 but India has still a long way to go towards achieving this goal. Since, there is no specific treatment for rubella infection, vaccination is the primary means of preventing CRS.

\section{CONCLUSION}

This study indicate that a substantial number of adolescent girls will reach childbearing age without immunity against rubella and are thus at an increased risk of acquiring the infection during pregnancy. This in turn will infect the foetus which may result in congenital rubella syndrome. With the introduction of rubella vaccine, it is necessary to monitor the trends of rubella susceptibility among adolescent girls by conducting periodic sero-surveys in selected areas and motivate them to get vaccinated.

\section{Funding: No funding sources}

Conflict of interest: None declared

Ethical approval: The study was approved by the Institutional Ethics Committee

\section{REFERENCES}

1. Burchett SK. Viral Infections. In: Cloherty JP, Eichenwald EC, Hansen AR, Stark AR (eds.), Manual of neonatal care, $7^{\text {th }}$ ed, Wolters Kluwer India Pvt Ltd. 2012;619-622.

2. Mason WH. Rubella. In: Kliegman RM. Mason WH. Rubella. In: Kliegman RM, Stanton BF, Joseph W. St. Geme, Schor NF, Behrman RE (eds.), Nelson Textbook of pediatrics, $20^{\text {th }}$ edn, Elsevier Division of Reed Elsevier India Pvt Ltd.; 2016:3085-3100.

3. Papania MJ, Wallace GS, Rota PA, Icenogle JP, Fiebelkorn AP, Armstrong GL, et al. Elimination of endemic Measles, Rubella, and congenital rubella syndrome from the western hemisphere: the US experience. JAMA Pediatr. 2014;168(2):148-55.

4. Dewan P, Gupta P. Burden of Congenital Rubella Syndrome (CRS) in India: a systematic review. Indian Pediatr. 2012;49:377-99.

5. Vashishtha VM, Choudhury P, Kalra A, Bose A, Thacker N, Yewale VN, et al. Indian Academy of Pediatrics (IAP) recommended immunization schedule for children aged 0 through 18 years - India, 
2014 and Updates on Immunization. Indian Pediatr. 2014;51:785-800.

6. WHO Regional Committee for Europe resolution EUR/RC60/R12 on renewed commitment to elimination of measles and rubella and prevention of congenital rubella syndrome by 2015 and sustained support for polio-free status in the WHO European Region. Copenhagen: WHO Regional Office for Europe; 2010.

7. Ramya R, Ramesh S, Ramesh J. Rubella seroprevalence among unvaccinated adolescent girls in Chennai. Int J Pharm Bio Sci. 2017;8(1):163-6.

8. Ramamurty N, Murugan S, Raja D, Elango V. Serosurvay of rubella in five blocks of Tamil Nadu. The Indian J Med Res. 2006;123(1):51-4.
9. Sharma HJ, Padbidri VS, Kapre SV, Jadhav SS, Dhere RM, Parekh SS, et al. Seroprevalence of rubella and immunogenicity following rubella vaccination in adolescent girls in India. The $\mathrm{J}$ Infect Develop Countr. 2011;5(12):874-81.

Cite this article as: Prasad D, Prasad N, Prakash V, Parven S, Mishra U. Sero-prevalence of unvaccinated adolescent girls susceptible to rubella virus infection seen in a tertiary care hospital of Patna, Bihar, India. Int J Reprod Contracept Obstet Gynecol 2020;9:1972-5. 